\title{
Experimental Infection of Swiss Albino Mice with Clostridium Chauvoei
}

\section{Muhammad Ismail Qureshi ${ }^{1}$, Dildar Hussain Kalhoro ${ }^{1}$, Mansoor Tarigue Samo ${ }^{1}$, Shahid Hussain Abro ${ }^{1}$, Ghulam Mustafa Solangi ${ }^{2}$, Abdul Ahad Soomro ${ }^{3}$, Shahjahan Qaim Khani ${ }^{1}$, Ismail Brohi ${ }^{1}$, Ismail Qaim Khani ${ }^{1}$, Waseem Baloch ${ }^{1}$, Sundesh Kumar OAd ${ }^{1}$}

${ }^{1}$ Department of Veterinary Microbiology, Faculty of Animal Husbandry E Veterinary Sciences, Sindh Agriculture University, Tandojam, Sindh-Pakistan; ${ }^{2}$ Vaccine Production Unit (VPU) Tandojam, Sindh-Pakistan. 3Central Veterinary Diagnostic Laboratory Research E Diagnosis (CVDL) Tandojam, Sindh-Pakistan.

\begin{abstract}
Clostridium Chauvoei is an anaerobic, endospore forming gram-positive organism causing black quarter, a deadly disease of domestic animals. A total of 30 Swiss albino mice weighting between 18-20g were used for experiment. In this study, the bacterial load, pathological lesions and histopathological changes in heart, liver and thigh muscles of swiss albino mice caused by Clostridium Chauvoeiat1d.p.i, 2d.p.i, 3d.p.i, 4d.p.i and 5d.p.i (Days post infection) respectively investigated and it was observed that the bacterium Clostridium Chauvoei produced more severe pathological changes in heart, liver and thigh muscles respectively. Necrosis was observed in the tissues examined, both grossly and histopathologically. It is concluded from the present study that, Clostridium Chauroei is potentially pathogenic and its play an important role in the mechanisms of blackleg in swiss albino mice, they can be particularly important to study its pathogenic characteristics.
\end{abstract}

Keywords: Experimental infection, Swiss albino mice, Clostridium Chauvoei

\author{
Editor | Muhammad Nauman Zahid, Quality Operations Laboratory, University of Veterinary and Animal Sciences, Lahore, Pakistan. \\ Received | December 29, 2019 Accepted | May 23, 2020; Published | June 26, 2020 \\ *Correspondence | Muhammad Ismail Qureshi, Department of Veterinary Microbiology, Faculty of Animal Husbandry \& Veterinary Sciences, Sindh Agricul- \\ ture University, Tandojam, Sindh-Pakistan; Email: drismailqureshi786@gmail.com \\ Citation | Qureshi MI, Kalhoro DH, Samo MT, Abro SH, , Solangi GM, , Soomro AA, Khani SQ, Brohi I, Khani IQ, Baloch W, Oad SK (2020). Experimental \\ infection of swiss albino mice with Clostridium Chauvoei. S. Asian J. Life Sci. 8(1): 19-23. \\ DOI | http://dx.doi.org/10.17582/journal.sajls/2020/8.1.19.23 \\ ISSN | 2311-0589
}

Copyright $(\subset) 2020$ Qureshi et al. This is an open access article distributed under the Creative Commons Attribution License, which permits unrestricted use, distribution, and reproduction in any medium, provided the original work is properly cited.

\section{INTRODUCTION}

$\mathrm{T}$ he bacterium Clostridium Chauvoei causes a disease known as black leg that is characterizes by inflammation of thigh muscles, severe toxemia and high mortality in cattle, sheep and many other domestic and wild animals (Jowel et al., 2016, Rajalakshmi et al., 2010). It is the second most important bacterial disease in the world next only to haemorrhagic septicemia causing death among bovids (Useh et al., 2012). Clostridium Chauvoei is a gram positive, rod shaped anaerobic and endospore forming bacterium (Fatiha et al., 2015, Zahid et al., 2012). The genus Clostridium produces tetanus (lock jaws), botulism (food poisoning) and enterotoxaemia. Blackleg disease is mostly affecting young animal's ages between 6 to 24 months (Langroudi et al., 2012, Radostits et al., 2000).
The organism is widespread but is more prevalent in certain geographic areas and can survive for many years without losing its pathogenicity Collier et al. (1998). The Clostridium Chauvoei species are generally spread in the soil and some of them also live in human and animal intestinal tract, where they are metabolically active and versatile Jowel et al. (2016). Mice are ideal laboratory animals to study the experimental bacterial infection and their pathogenesis, so the present study was designed to investigate the bacteremia and severity of pathological lesions of induced Clostridium Chauvoei in Swiss albino mice.

\section{MATERIAL AND METHODS}

\section{Bacteria Strain}

The (hershey strain) was used for the research. 


\section{Preparation of Media and Fresh Cultures}

Reinforced Clostridial Medium (RCM) was prepared by taking $50 \mathrm{~g}$ media by adding $1000 \mathrm{ml}$ distilled water and autoclave at $121^{\circ} \mathrm{C}$ for 20 minutes.

The pure bacterial seed of Clostridium Chauvoei was cultured and activated by giving 3-4 passages in a specific Reinforced Clostridial Medium (RCM agar and RCM broth). Challenged organism was enumerated by plate count method to determine CFUs /ml. The actual mean dose was determined by viable/plate counts Sugun et al. (2007).

\section{Experimental Animals And Inoculation Of Spores}

Thirty specific pathogens free (SPF) swiss albino mice, each weighting between 18-20g were obtained from animal house of Vaccine Production Unit (VPU), Tandojam. Mice were divided into 3 groups, each group contain 03 mice and identified as groups $\mathrm{A}, \mathrm{B}$ and $\mathrm{C}$ respectively. Group $\mathrm{C}$ served as control. Spores were diluted in phosphate buffer saline (PBS) and were orally inoculated 0.1 $\mathrm{ml}\left(1 \times 10^{-5}\right)$.

\section{Gross and Histopathological Examination of Carcasses}

Gross lesions and tissue sections for histopathology were obtained from various organs. For histopathology, tissues were preserved and fixed in $10 \%$ formalin for at least 48 $\mathrm{h}$. The tissues were sectioned at 5-6 $\mu \mathrm{m}$ and stained with haematoxylin and eosin (H\&E).

\section{RESULTS}

\section{Gross Lesions in Mice}

The gross lesions in mice experimentally injected spores of Clostridium Chauvoei toxins were observed after 24 and 48 hrs.

Necrosis, myositis and hemorrhages were observed in thigh muscle (Figure 1) whereas, dark blackish color and necrosis was observed in heart (Figure 2) whereas, hepatomegaly, greenish color was seen in liver of swiss albino mice infected with Clostridium Chauvoei (Figure 3).

\section{BACTERIAL LOADS}

The Bacterial loads in the heart, liver and thigh muscle of mice infected with Clostridium Chauvoei is presented in (Graph 1). Ten mice from group A were orally inoculated with $0.1 \mathrm{ml}\left(1 \times 10^{-5}\right) \mathrm{CFU} / \mathrm{ml}$, At 1 day post infection bacterial load in heart and thigh muscle was more than $10^{1} \mathrm{CFU} / \mathrm{g}$ whereas, bacterial load in liver more than $10^{2}$ $\mathrm{CFU} / \mathrm{g}$. At 2 days post infection bacterial loads in heart was $10^{2} \mathrm{CFU} / \mathrm{g}$, in thigh muscle it was $10^{3} \mathrm{CFU} / \mathrm{g}$. where- as, bacterial load in liver $10^{4} \mathrm{CFU} / \mathrm{g}$. At 3 days post infection bacterial load in heart more than $10^{3} \mathrm{CFU} / \mathrm{g}$, in thigh muscle it was more than $10^{4} \mathrm{CFU} / \mathrm{g}$ and more than $10^{5} \mathrm{CFU} / \mathrm{g}$ was observed in liver. At 4 days post infection bacterial load in heart was $10^{5} \mathrm{CFU} / \mathrm{g}$, in thigh muscle it was $10^{6} \mathrm{CFU} / \mathrm{g}$, whereas bacterial load in liver was more than $10^{5} \mathrm{CFU} / \mathrm{g}$. At 5 days post infection bacterial load in heart was $10^{6} \mathrm{CFU} / \mathrm{g}$, in thigh muscle it was more than $10^{6} \mathrm{CFU} / \mathrm{g}$, whereas bacterial load in liver was $10^{7} \mathrm{CFU} / \mathrm{g}$.

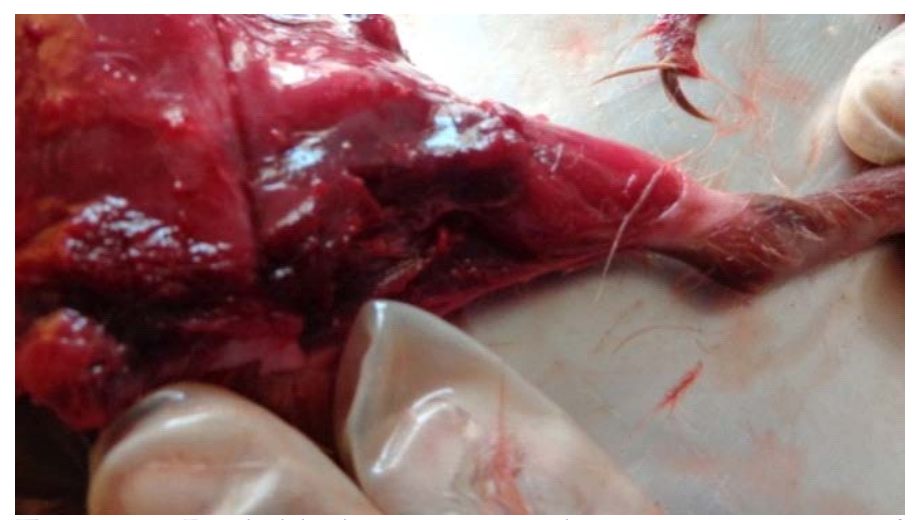

Figure 1: Dark black necrotic with severe myositis and hemorrhages in thigh muscles of Swiss albino mice infected with Clostridium chauvoei.

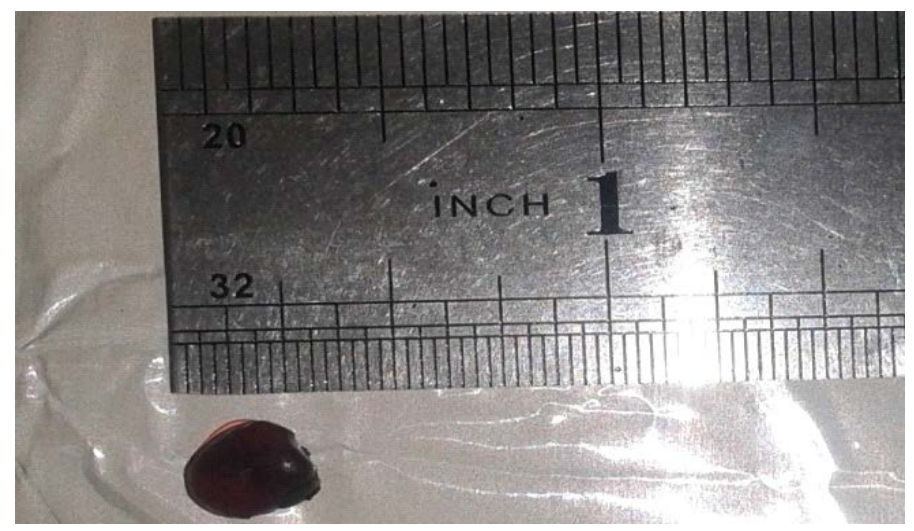

Figure 2: Inflammation, dark black of heart muscles infected with Clostridium Chauroei in Swiss albino mice.

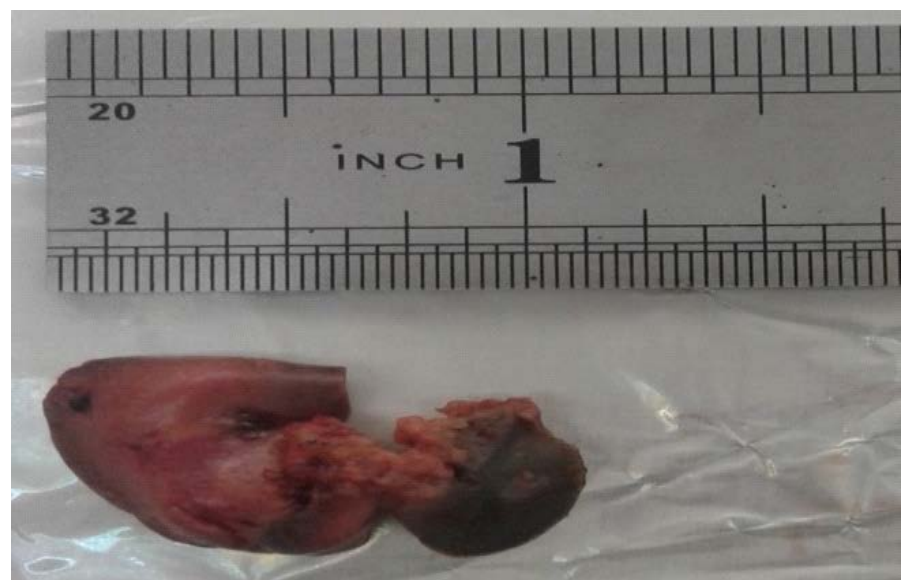

Figure 3: Dark black and greenish color due to necrosis and hepatomegaly due to infection of Clostridium Chauvoei in liver of Swiss albino mice. 


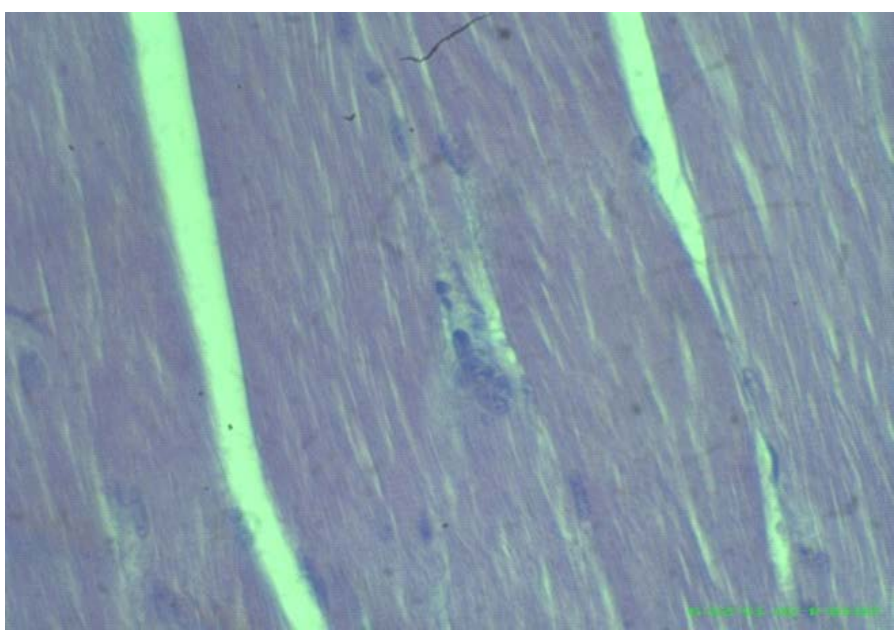

Figure 4: Uniform and dense striated muscles of thigh and intramuscular gases accumulate (arrows), (H\&E staining at 40x magnifications).

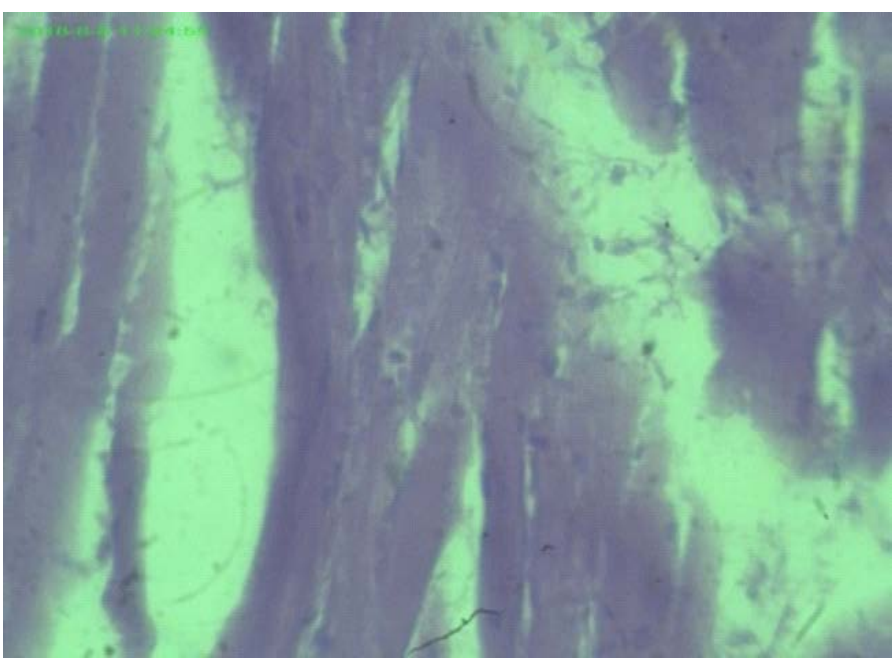

Figure 5: Myocardial fiber attenuation and separation, disarray of myofibrils (arrows), (H\&E staining at 40x magnifications).

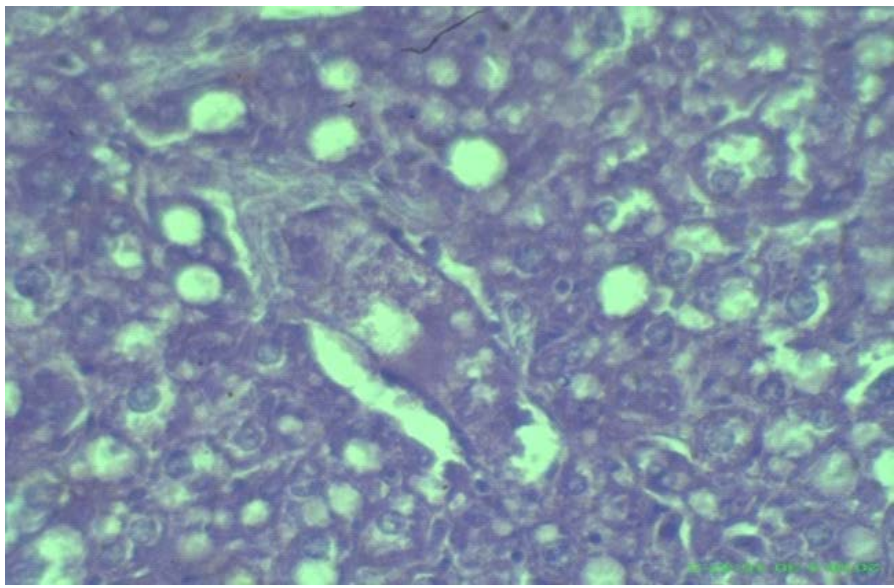

Figure 6: Edematous, swollen hepatocytes and multifocal hepatic necrosis lesions (arrows), (H\&E staining at 40x magnifications).

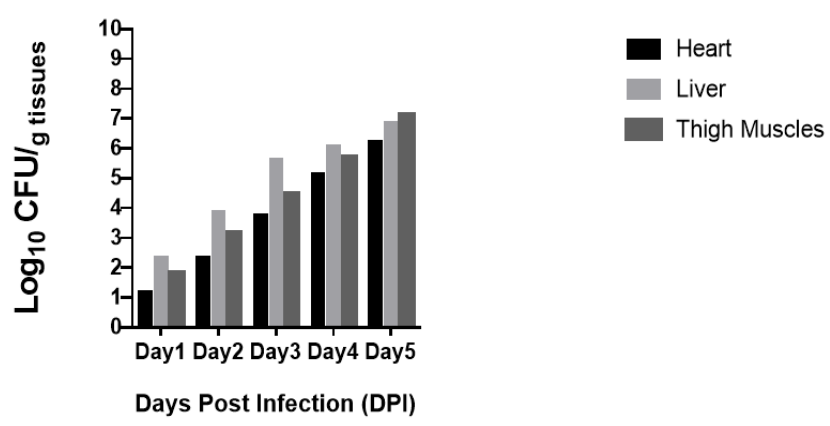

Graph 1: Bacterial load in heart, liver and thigh muscles after inoculation of Clostridium Chauvoei in mice $0.1 \mathrm{ml}$ $\left(1 \times 10^{-5}\right) \mathrm{CFU} / \mathrm{ml}$. Bacteria are expressed as $\log 10$ number of CFU/gram of heart, liver and thigh muscle.

\section{DISCUSSION}

The bacterial loads in challenged animals swiss albino mice infected by Clostridium Chauvoei (hershey strain) at 1d.p.i, 2d.p.i, 3d.p.i, 4d.p.i and 5d.p.i (Days post infection) of orally inoculated spores respectively. In present study all experimental mice showed that, respiratory distress, convulsed while three (3) mice (30\%) died respectively. The similar findings supported by Xingminsun et al. (2011). They gave primary infection with $10^{6}$ of Clostridium difficile spores caused more than $95 \%$ of the animals to produce diarrhea, with a mortality rate of around $50 \%$ in mice. Another similar finding was supported by Maria et al. (2007). They were used four different doses of Clostridium Chauvoei as intragastric challenge at $10^{2}, 10^{3}, 10^{4}$ or $10^{5}$ CFU. Challenge $96 \%$ of mice becoming moribund on day 4. When doses of $10^{4}$ or $10^{3} \mathrm{CFU}$ were used, $50 \%$ of mice were survived on days 4 and 5 . The results were expressed as the sum of surviving mice/total challenged of two protection tests performed independently of each other Maria et al. (2007).

The gross lesions observed in the heart, liver and thigh muscles of swiss albino mice inoculated with Clostridium Chauvoei spores at 1d.p.i, 2d.p.i, 3d.p.i, 4d.p.i and 5d.p.i (Days post infection) were effectively similar and these include necrosis, myositis, swollen, and dark red or infiltrated with blackish color hemorrhages (Figure 1) Malone et al. (1986). The present study is also in agreement with, Naz et al. (2005). Who examined gross lesions in thigh muscles of mice and reported that affected muscles were reddish and blackish in color Daly et al. (2009). Reported evidence of necrosis in thigh muscles, Malone et al. (1986), Daly et al. (2009).The most prominent necropsy findings in the current study were observed in heart muscles of mice inoculated of spores of Clostridium Chauvoei. After postmortem examination, the dark black hemorrhagic heart muscles 
blackish color hemorrhages and rancid odor. Findings of current study are agreement with (Naz et al., 2005). Who reported heart with blackish color, glossy surface and entire margin was surrounded by narrow zone of hemolysis. The findings of current study are also supported by (Jackson et al., 1995). Those reported inflamed cardiac muscles, necrotic myocarditis (Daly et al., 2009), fibrinous pericarditis (Malone et al., 1986), most prominent necropsy findings in the liver of mice were enlargement in size, hypertrophy, and light greenish in color. Microscopically, the Clostridium Chauvoei produced hepatocytes dense and multifocal hepatic necrotic lesions, in liver myocarditis, hemorrhages, congestion, in heart. Thigh muscles showed uniform, dense striated, necrotic myositis intramuscular gases accumulate, muscle fibers were moderately hypereosinophilic, the blood vessels were engorged with blood and the interstitium was distended with fluid and many leukocytes. These findings supported by (Maria et al., 2007, Naz et al., 2005). Who reported general collapse, coagulative necrosis of thing muscle fibers. Our findings are supported by (Araujo et al., 2010). Who reported congestion and edematous, hyperemia and centrilobular necrosis of the liver, whitish grey liver, glossy surface and entire margin surrounded by narrow zone of hemolysis (Naz et al., 2005, Daly et al., 2009), gaseous edema of liver muscle, severe toxemia, gas gangrene and anemia (Useh et al., 2012, Prhiscylla et al., 2012).

\section{CONCLUSION}

It is concluded that, mice are susceptible experimental animals to observe Clostridium Chauvoei infection. However higher bacterial loads CFU/g were observed in liver, thigh muscles and heart in swiss albino mice infected with Clostridium Chauvoei respectively. Further investigation shows that gross pathological lesions including necrosis, myositis and hemorrhages were observed on heart, liver and thigh muscles of infected mice respectively. Histo-pathological lesions observed were hepatocytes dense and multifocal hepatic necrosis lesions myocardial hemorrhages in mice.

\section{Data Analytical}

M stat-c, MS excel, and graphpad prism software were used for data analysis and making graph.

\section{ACKNOWLEDGMENT}

The authors highly acknowledged the Faculty of Animal Husbandry \& Veterinary Sciences, Sindh Agriculture University Tandojam, Sindh-Pakistan, Vaccine Production Unit (VPU), Tandojam, Sindh and Central Veterinary Diagnostic Laboratory (CVDL) Tandojam, Sindh-Pakistan for providing research facilities to carry out some part of this work and their inputs and guidelines during this manuscript.

\section{AUTHOR CONTRIBUTIONS}

Muhammad Ismail Qureshi conducted the research work, designed study, analyzed data and proof reading of manuscript. Dildar Hussain Kalhoro helped during written manuscript and Gulam Mustafa Solangi, Abdul Ahad Soomro helped during conducting research.

\section{REFERENCES}

- Araujo RF, VC Curci (2010). Vaccination protocol and bacterial strain affect the serological response of beef calves against blackleg. Pesq. Vet. Bras. 30: 554-558. https://doi. org/10.1590/S0100-736X2010000700008

- Collier L, A Balows, M Sussman (1998). Topley and Wilson's Microbiology and Microbial Infections. $9^{\text {th }}$ Ed., Arnold, London, UK: 250-300.

- Daly RF, DW Miskimins, RG Good, T Stenberg (2009). Blackleg (Cl.chauvoei infection) in beef calves: a review and presentation of two cases with uncommon pathologic presentations. J. Bov. Practit. 43 (2): 153-158.

- Fatiha G, Mohamed Amine M, Nawel K, Rabah B (2015). Study of Vaccinal Properties of Clostridium Chauvoei Strains Isolated during a Blackleg Outbreak in Cattle in Algeria. Kafkas, Uni, Vet. Fak. Derg. 21: 825-829.

- Jackson CA (1995). Histology of blackleg disease. A Handbook of DC Blood. Comp. Cont. Edu. Pract. Vet. 17 (10): 1299.

- Jowel MS, MSR. Khan, MS Parveja (2016). Characterization and antibiogram study of Clostridium Chauvoei isolated from field cases of black leg in cattle. Bangl.J. Vet. Med. 14: 53-57 https://doi.org/10.3329/bjvm.v14i1.28824.

- Langroudi RP, AR Jabbari, MM Shoshtari (2012). Large scale production of Blackleg vaccine by fermenter and enriched culture medium in Iran. Arch. Razi Inst. 67: 43-49.

- Maria A Mattar, M. Stefanini (2007). Extracellular proteins of Clostridium Chauvoei are protective in a mouse model. Acta. Vet. Hung. 55: 2: 159-170. https://doi.org/10.1556/ avet.55.2007.2.1

- Malone FE, PJ McParland, JO Hagan (1986). Pathological changes in the pericardium and meninges of cattle associated with Clostridium Chauvoei. Vet. Rec.119:151-152. https:// doi.org/10.1136/vr.119.6.151

- Naz S, S Ahmed, JI Bhatti (2005). Isolation and identification of clostridium chauvoei from cattle and buffalo. Pak. Vet. J. 25: 101-102.

- Prhiscylla SP, E Roselene, RDA Marina (2012). Comparative analysis of lesions caused by histotoxic clostridia in experimentally induced myonecrosis. Rep. Semi. 33: 23372339. https://doi.org/10.5433/1679-0359.2012v33n6p2337

- PrincwillTJT(1965). Effect of calcium chloride on germination and pathogenicity of spores of Clostridium Chauvoei. J. Comp. Patho.75: 343-351. https://doi.org/10.1016/00219975(65)90041-1

- Radostits OM, CC Gay, DC Blood, KW Hindicliff (2000). Veterinary Medicine: A text book of diseases of cattle, sheep, pigs, goats and horses. $9^{\text {th }}$ Ed., W.B. Saund Comp Ltd., Lond, UK.

- Rajalakshmi A, TS Renuga Devi, S Gunasekaran (2010). 
Efficacy of Black Quarter Vaccine on Cattle: A Spectroscopic Approach. Asia Jour of Chem. 22: 2529-2536.

- Sugun MY, HM Kazeem, NDG Ibrahim, NM Useh (2007). Pathological changes in mice experimentally injected Clostridium Chauvoei toxins. J. Anim. Vet. Adv. 6: 234-237.

- Tajik J, T Khodakaram, A Derakhshandeh, AT Tajik (2013). Probable occurrence of black leg in a sucker dairy calf: then necessity of providing sufficient maternal antibody in endemic regions. Iran J. Vet. Med. 7: 69-72.
- Useh, N M (2012). Anaemia in Clostridium Chauvoei infection is masked by haemoconcentration. Vet, arski, Arhiv. 82: 5: 433-447.

- Xingminsun, Haiying W, Yongrong Z (2011). Mouse Relapse Model of Clostridium difficile Infection. Infec. Immun. 79: 2856-2864. https://doi.org/10.1128/IAI.01336-10

- Zahid UN, SM Kumar, SS Randhawa (2012). Black Quarter in crossbred dairy cattle- A Case Report. Vet. World. 5.12: 767-770. https://doi.org/10.5455/vetworld.2012.767-770 